\title{
Differential tree recruitment in California oak savannas: Are evergreen oaks replacing deciduous oaks?
}

\author{
Ramón Perea ，Aida López-Sánchez , Rodolfo Dirzo
}

\begin{abstract}
A B S T R A C T
Understanding tree recruitment is crucial to assess species turnover in mixed forests and woodlands, particularly in light of current anthropogenic impact. Here, we investigate whether oak recruitment (density of young oaks) in co-existing deciduous and evergreen oaks is disproportional to the abundance of their corresponding reproductive trees, favoring regeneration of some species over others, which may anticipate a future species turnover. We also examined whether browsing damage and microsite location play a differential role in such recruitment process.

We uncovered an overall underrepresentation of young oaks $(<7.5 \mathrm{~cm} \mathrm{DBH})$ in both deciduous species ( $Q$. lobata and $Q$ douglasii), compared to the evergreen oak ( $Q$ agrifolia), even in areas where deciduous species were the locally predominant mature trees. Such differential recruitment was accentuated in areas where $Q$. lobata was predominant, with young evergreen oaks reaching densities 3-times higher than those of the deciduous oak. Recruitment of all three species was significantly associated with shrub cover, suggesting a facilitative effect, via reduction of both occurrence and intensity of herbivory. However, evergreen oaks were much less vulnerable to herbivory (lower occurrence and intensity) than deciduous oaks and, thus, evergreen recruits were able to thrive even in uncovered areas. Overall, our results provide evidence of differential recruitment at the juvenile stage in co-occurring oak species, which may lead to a replacement of deciduous species with evergreen oaks. The disproportionate effect of shrubs as safe microsites for regeneration of both deciduous and evergreen species suggests that herbivory pressure is an important factor reducing the abundance and heterogeneity of favorable regeneration niches, particularly for the most herbivore-sensitive tree species. Further studies should address to what extent the recruitment patterns described here translate into future differences in adult stages, and whether the actual biased regeneration is mostly due to differential herbivory on deciduous vs. evergreen species. We posit that, for the management and conservation of multi-specific oak savannas, regeneration of deciduous oaks should be prioritized over that of live oaks in order to maintain greater levels of biodiversity and reduce biotic homogenization.
\end{abstract}

\section{Introduction}

Species coexistence within plant communities is determined by a combination of abiotic and biotic interactions, both positive and negative (Valladares et al., 2015). Increasingly, through modifications of biotic and abiotic factors, human activity is negatively impacting tree populations and altering species coexistence across the globe (Crowther et al., 2015). Detailed understanding of tree recruitment is essential to understand possible effects of anthro- pogenic change on species coexistence and plant communities. In tree-dominated communities, in particular, species turnover (i.e., changes in species composition through colonization and extinction) is a long-lasting process that typically requires long-term research and detailed knowledge of the recruitment process (Bakker et al., 1996; Ibañez et al., 2008; Pérez-Ramos et al., 2012).

Oaks (Quercus spp.) are often a dominant component of forest, woodland, and shrubland communities across the Northern Hemisphere (including Mesoamerica), with more than 500 extant species (Nixon, 1993). Oak-dominated systems cover vast areas of temperate and Mediterranean regions, and represent highly valuable and diverse systems, both ecologically and socioeconomically, providing numerous goods and services to society (Campos et al., 2013; Davis et al., 2016). However, throughout the world, a lack 
of natural regeneration has been reported in many oak woodlands, forests and savannas of Asia, Europe and North America (Muick and Bartolome, 1987; Plieninger, 2006; Tyler et al., 2006; Zavaleta et al., 2007; Campos et al., 2013; López-Sánchez et al., 2016). This shortage of tree recruitment is critical and represents a long-recognized threat for the persistence of many scatteredoak woodlands - known as oak savannas - worldwide (Griffin, 1971; McClaran and Bartolome, 1989; Manning et al., 2006; Fischer et al., 2009; Bergmeier et al., 2010; Perea et al., 2016). The failure of oak recruitment has been mostly attributed to the high intensity and permanent herbivory pressure (browsing) exerted by wild and domestic ungulate overgrazing over the last decades (Bartolome et al., 1987; Pulido et al., 2001, 2010; Plieninger et al., 2003; Tyler et al., 2006, 2008; Perea et al., 2014; López-Sánchez et al., 2014, 2016), although other factors have also been identified, including competition with grasses (Griffin, 1971; Gordon and Rice, 2000), and increased drought stress (Gómez-Aparicio et al., 2008a; Mahall et al., 2009; McLauglin and Zavaleta, 2012; Davis et al., 2016) among others.

California oak woodlands and savannas are diverse systems that harbor complex networks of species interactions (Davis et al., 2016) and support more than 1400 species of flowering plants and over 300 species of vertebrates (Tyler et al., 2006). Covering approximately 9\% of California's mainland (Davis et al., 2016), these oak-dominated systems are primarily threatened by introduced pathogens, invasive species, overgrazing, and land use and climate change (Kueppers et al., 2005; Tyler et al., 2006; Davis et al., 2016). Commonly, recruitment levels in oak woodlands do not appear to be sufficient to sustain populations, particularly of two widespread deciduous species in Northern California, the blue oak (Quercus douglasii), and the valley oak (Q. lobata), raising concern for the future of such ecosystems (Tyler et al., 2006; Zavaleta et al., 2007; Davis et al., 2011; Pearse et al., 2014). Regional climate models predict a $60 \%$ decrease of current potential habitat for both deciduous species by late 21 st century (Kueppers et al., 2005) and, the potential ability of these species to track areas of future suitable climate depends on effective dispersal and recruitment. In contrast, evergreen oak species, known as live oaks (e.g., Q. chrysolepis, Q. wislizenii and Q. agrifolia) seem to be regenerating more consistently (Griffin, 1976; McMahon et al., 2015). This difference in regeneration ability has been traditionally associated, but not fully evaluated, with the greater browsing-resistance of live oaks, compared to deciduous oaks (Griffin, 1971); or with the lack of ground fires that would impact live oak seedlings without seriously damaging the "ground-fire adapted" valley oaks (Griffin, 1976). A recent study on oak seedlings in mixed oak woodlands points out that $Q$. lobata seedlings are underrepresented in the understory of their mature trees (Pearse et al., 2014), suggesting a possible differential recruitment at the seedling stage. The question then arises as to whether recruitment success in co-existing oak species under anthropogenic impact is currently unbalanced, favoring regeneration of some species over others, prompting concern for future species turnover with the replacement or local extinction of the most vulnerable species. Thus, a better understanding of the factors controlling tree recruitment in co-dominated oak woodlands is of key importance for the management and conservation of these highly valuable ecosystems.

Previous work on oak regeneration in Mediterranean environments has shown that regeneration microsites are crucial for successful recruitment. At many sites, shrub cover has been found to facilitate oak recruitment (Callaway, 1992; Callaway and Davis, 1998; Pulido and Díaz, 2005; Zavaleta and Kettley, 2006; Perea et al., 2016), mostly due to the "nursing" effects of some shrubs against herbivory and desiccation (Callaway and D'Antonio, 1991: Gómez-Aparicio et al., 2008b; Perea and Gil, 2014a, 2014b). However, other studies have found no evidence of shrub facilitation for certain oak species (e.g., Q. lobata), while regeneration of other sympatric species ( $Q$. douglasii and $Q$. agrifolia) seems to be strongly associated with the presence of shrubs (Callaway, 1992; Callaway and Davis, 1998). This suggests that the relative importance of safe microsites (i.e., shrubs) may also depend on the identity of the beneficiary species. Different degrees of microsite facilitation might therefore contribute to explain differences in regeneration niche (sensu Grubb, 1977) across species, favoring species coexistence (Grubb, 1977; Hulme, 1996). Therefore, changes in microsite abundance could positively affect oak recruitment of some species over others, facilitating species turnover. However, to our knowledge, no study has simultaneously explored species turnover (successful recruitment under conspecifics and other co-dominant oak trees), and the possible differential effect of microsites on tree recruitment for co-existing oak species.

Here we analyze oak recruitment of three co-existing species including one evergreen (Q. agrifolia) and two deciduous ( $Q$. lobata, Q. douglasii) oak species across the three main microsite types (open, under shrub, under tree) in California oak savannas. We specifically investigate whether (1) tree recruitment is proportional to the abundance of their corresponding reproductive tree species; (2) microsite effect on recruitment is similar across the three co-existing species, and (3) the probability and intensity of herbivory damage varies among oak species and microsite type. We specifically predict, respectively, that (1) oak recruitment (density of young plants) will be proportional to the relative abundance of its mature oak species; (2) oak recruitment would be proportionally more abundant under protective microsites (shrubs and trees) for all oak species, and (3) browsing probability and intensity on young oaks would be lower under shrubs than under any other microsite for the three study oaks. This study aims to improve our understanding of species coexistence (regeneration niche) and the vulnerability of multi-specific oak systems to species turnover and possible local extinction.

\section{Material and methods}

\subsection{Study area}

The study was conducted in two sites located in the interior foothills of Northern California, USA: Stanford's Jasper Ridge Biological Preserve (JRBP) and the Stanford Dish Area (SDA). JRBP $\left(37.40^{\circ} \mathrm{N}, 122.23^{\circ} \mathrm{W}\right)$ is a 480 -ha research preserve located in the foothills of the Santa Cruz Mountains. JRBP has a coastal Mediterranean climate, with warm, dry summers and cool, wet winters. Mean annual precipitation is $605 \mathrm{~mm}$ and average daily temperatures range from 2 to $4{ }^{\circ} \mathrm{C}$ in winter, and from 25 to $27^{\circ} \mathrm{C}$ in summer (Zavaleta and Kettley, 2006). Elevation ranges from 66 to $207 \mathrm{~m}$ a.s.l. JRBP supports diverse vegetation types including grassland, woodland, chaparral and forest. Oak-dominated systems (woodlands and savannas) are the most common vegetation type at JRBP. Oak systems are dominated by an evergreen oak tree, coast live oak (Quercus agrifolia Née), and two deciduous oak species: valley oak ( $Q$. lobata Née) in deeper soils, and blue oak ( $Q$. douglasii Hook. \& Arn.) in shallower, drier soils. Prior to establishment as a research preserve in 1973, the area was subject to logging, recreational use, and livestock grazing (Bocek and Reese, 1992).

The Stanford Dish Area $\left(37.41^{\circ} \mathrm{N}, 122.18^{\circ} \mathrm{W}\right)$, located about $6 \mathrm{~km}$ East from JRBP, covers $560 \mathrm{ha}$, and is currently used for recreational and academic purposes. Climate, vegetation (oakdominated systems) and historical land use for SDA are similar to those of JRBP, though heavy disturbance from recreational use has continued on particular, designated areas, until the present day (Palmer, 2003). Livestock (mostly cattle) was removed from JRBP in 1973, and from SDA (study sites) in 1982-1988. Black- 
tailed deer (Odocoileus hemionus) is the main browser and the only ungulate present in both JRBP and SDA. So far, important diseases that cause extensive oak mortality, such as sudden oak death (Phytophthora ramorum) have not been found in the study area. Annual precipitation of the study year (October 2013-October 2014) was $300.5 \mathrm{~mm}$ (50\% lower than average).

\subsection{Data collection}

Only oak savannas (open woodlands with scattered oak trees) were considered for the purpose of this study, following the vegetation maps of JRBP and SDA. A total of 32 randomly located belt transects ( $30 \mathrm{~m}$ long $\times 4 \mathrm{~m}$ wide) were established (16 in JRBP and 16 in SDA) throughout the study area (1040 ha). We classified the three oak species ( $Q$, agrifolia, $Q$. lobata, and $Q$. douglasii) in two age classes: young trees, with diameter at breast height (DBH) $<7.5 \mathrm{~cm}$, and adult trees, with $\mathrm{DBH} \geq 7.5 \mathrm{~cm}$. We counted all young and adult oaks within each transect. For each young oak, we recorded species, height, basal diameter, and the microsite type in which it was found: open grasslands (hereafter open), under tree canopy (hereafter tree) and under shrub canopy (hereafter shrub). Additionally, we estimated browsing intensity for each young tree, using a 6-points rank (0-5) of an ordinal scale, following Perea et al. (2015): $0=$ No browsing evidence; $1=$ Light browsing with $<10 \%$ twigs browsed; 2 = Low browsing, with $10-30 \%$ of twigs browsed; $3=$ Intense browsing (30-60\% of the twigs); $4=$ Heavy browsing ( $>60 \%$ of the twigs), with clear modification of plant shape; $5=$ Maximum browsing ( $>90 \%$ of the twigs browsed). For each adult tree within the transect we recorded species and DBH. Within the entire transect, we recorded the number of groups of deer scat pellets as a proxy for herbivore abundance. In addition, for each transect we recorded the relative abundance of each microsite by measuring the length of each microsite intercepting a transect tape placed along the $30 \mathrm{~m}$ central axis of the transect. Shrubs and trees were identified to species. Based on the relative abundance of each oak species in the overstorey (adult tree cover within the transect) we classified each transect as $Q$. lobata-, Q. agrifolia- or Q. douglasii-dominated. Surveys were conducted in late September-early October 2014, after a long summer drought, to avoid the inclusion of recently established seedlings $(0-1$ years old), given that first-year survival is critical but very low for California oaks (Tyler et al., 2008).

\subsection{Statistical analysis}

Data processing and statistics were performed using R 3.2.4 ( $R$ Core Team, 2016) with the modules "car" (Fox and Weisberg, 2011), "MuMIn" (Barton, 2015) and "nnet" (Venables and Ripley, 2002).

In order to analyze natural regeneration (density of young oaks) we used Generalized Linear Models (GLMs; Dobson, 2002). Number of all young oak plants found in each transect was the response variable (count data). The following variables were included in the models as predictors: microsite type where each young oak was found, oak species (number of young oaks of $Q$. agrifolia, $Q$. douglasii and $Q$. lobata), overstorey predominant tree species within the transect $(Q$. agrifolia, $Q$. douglasii, $Q$. lobata), and site (JRBP, SDA). Since the abundance of each microsite type differed among sites and transects, we included a new predictor in the model to correct for uneven microsite abundance. This correction allowed us to factor in possible microsite effects on oak regeneration. The new variable was the abundance of each microsite in each transect (i.e., number of meters of each microsite contacting the transect tape). For this variable we used the command "offset", which allowed us to correct for microsite effect without obtaining estimates for the model (Zuur et al., 2009). Interactions between microsite and young oak species, and between overstorey tree species and young oak species were also included in the model. The number of young plants was fitted to a negative binomial error distribution with a $\log$ link function.

Herbivory occurrence (presence-absence of browsing) on young oaks was analyzed using another GLM (binomial error family with a logit link). Intensity of herbivory ( $0-5$ browsing categories) on young oaks was also analyzed using multinomial log-linear models (multinomial error distribution with a cumulative logit link; Venables and Ripley, 2002). Both models included the following predictors: microsite type where young oaks were found (open, tree and shrub), oak species of young plants ( $Q$ agrifolia, $Q$. douglasii, Q. lobata), and site (JRBP and SDA). Finally, we used a GLM (Poisson error distribution; count data) to analyze possible differences in deer pellet groups per transect between JRBP and SDA.

We used the model averaging approach (Burnham and Anderson, 2002) in all models. We first fitted the maximal model, containing all the predictors. Then, we compared all possible models based on AIC weights. For model comparison we used the "dredge" function within the "MuMIn" package of R. Finally, we obtained the model-averaged coefficients as well as the relative importance of each predictor (from 0 to 1 ) by using the "model. avg" function of "MuMIn". We calculated the explained deviance as well as the dispersion parameter of each model to evaluate its fit and avoid overdispersion (Crawley, 2012).

\section{Results}

\subsection{Density of young oak plants}

We found that the density of young oak plants significantly differed depending on the overstorey predominant tree species in the transect, the microsite type and the oak recruitment species (Table 1; $N=287$ plants). In areas where adults of $Q$. agrifolia and Q. douglasii were predominant in the overstorey, the overall density of young oak plants (of all species) was significantly greater ( 0.38 and 0.26 plants per $4 \mathrm{~m}^{2}$, respectively; Fig. 1 , Table 1$)$ than in $Q$. lobata-overstorey areas ( 0.17 plants per $4 \mathrm{~m}^{2}$; Fig. 1$)$. However, no significant differences were found in the overall oak regeneration (across all oak species) between $Q$ douglasii- and $Q$. agrifolia-overstorey areas (Fig. 1). Overall, we found higher density of young $Q$. agrifolia oaks ( 0.20 plants per $4 \mathrm{~m}^{2}$; Fig. 1) compared with the other two species $\left(0.04\right.$ and 0.02 plants per $4 \mathrm{~m}^{2}$ for $Q$. douglasii and Q. lobata, respectively; Fig. 1, Table 1). Furthermore, Q. agrifolia regeneration (density of young oaks) was significantly greater even in those areas where the other two oak species were predominant (Fig. 1). Thus, in areas where $Q$. lobata was predominant in the overstorey, density of $Q$. agrifolia young plants was 3 -fold greater $\left(0.12\right.$ plants per $4 \mathrm{~m}^{2}$; Fig. 1$)$ than that found for Q. lobata (0.04 plants per $4 \mathrm{~m}^{2}$; Fig. 1). Similarly, in areas where $Q$. douglasii was predominant in the overstorey, density of young $Q$ agrifolia was 1.60 -fold greater $\left(0.16\right.$ plants per $\left.4 \mathrm{~m}^{2}\right)$ than that found for $Q$. douglasii ( 0.10 plants per $4 \mathrm{~m}^{2}$; Fig. 1 ). Even though $Q$. agrifolia regeneration was consistently more abundant across all areas, densities of young $Q$ douglasii and $Q$. lobata significantly increased in those areas in which their adults were predominant (Table 1; Fig. 1). However, there were no significant differences between $Q$. douglasii and $Q$. lobata regeneration densities when $Q$, agrifolia adults were predominant. Thus, we found very low but similar regeneration densities of $Q$. douglasii $\left(0.03\right.$ plants per $\left.4 \mathrm{~m}^{2}\right)$ and $Q$. lobata $\left(0.02\right.$ plants per $\left.4 \mathrm{~m}^{2}\right)$ in $Q$. agrifolia-overstorey areas.

Open areas and under tree cover were the most abundant microsites for all overstorey oak species (Fig. 2). Areas dominated by $Q$. agrifolia had, approximately, a 3 -fold greater proportion of 
Table 1

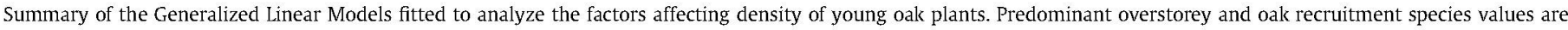
shown against Quercus agrifolia. Microsite effect is shown against open.

\begin{tabular}{|c|c|c|c|c|c|c|}
\hline Predictors & Relative importance & Factors & Coeff. & $S E$ & $z$-value & $P$ \\
\hline Intercept & - & & -1.305 & $2.58 \mathrm{e}^{-1}$ & 5.031 & $<0.001$ \\
\hline \multirow[t]{2}{*}{ Predominant overstorey (P) } & 1.00 & Q. douglasii (Q.d) & $-7.32 \mathrm{e}^{-1}$ & $5.17 \mathrm{e}^{-1}$ & 1.411 & 0.158 \\
\hline & & Q. lobata (Q.1) & -1.001 & $3.33 e^{-1}$ & 2.993 & 0.003 \\
\hline \multirow[t]{2}{*}{ Oak recruitment species $(0)$} & 1.00 & Q. douglasii (Q.d) & -2.485 & $3.96 \mathrm{e}^{-1}$ & 6.252 & $<0.001$ \\
\hline & & Q. lobata (Q.1) & -3.016 & $4.62 e^{-1}$ & 6.542 & $<0.001$ \\
\hline \multirow[t]{2}{*}{ Microsite (M) } & 1.00 & Shrub & $6.46 \mathrm{e}^{-1}$ & $3.17 \mathrm{e}^{-1}$ & 2.032 & 0.042 \\
\hline & & Tree & $5.44 \mathrm{e}^{-1}$ & $2.62 \mathrm{e}^{-1}$ & 2.072 & 0.038 \\
\hline Site $(S)$ & 0.34 & JRBP vs. SDA & $-2.21 \mathrm{e}^{-1}$ & $2.61 e^{-1}$ & 0.848 & 0.397 \\
\hline \multirow[t]{4}{*}{$\mathrm{P}^{*} \mathrm{O}$} & 0.99 & Q.d Q $^{*} d$ & 2.025 & $7.10 \mathrm{e}^{-1}$ & 2.523 & 0.012 \\
\hline & & Q. ${ }^{*} Q . d$ & $1.46 \mathrm{e}^{-1}$ & $7.09 \mathrm{e}^{-1}$ & 0.205 & 0.838 \\
\hline & & Q. * $^{*} \mathrm{Q} . \mathrm{I}$ & $-2.75 \mathrm{e}^{+1}$ & $6.17 \mathrm{e}^{+5}$ & 0.000 & 0.100 \\
\hline & & Q. $l^{*} \mathrm{Q} . \mathrm{l}$ & 1.907 & $6.24 \mathrm{e}^{-1}$ & 3.045 & 0.002 \\
\hline \multirow[t]{4}{*}{$\mathrm{M}^{*} \mathrm{O}$} & 0.02 & Shrub * Q.d & $-9.29 \mathrm{e}^{-1}$ & $9.40 \mathrm{e}^{-1}$ & 0.986 & 0.324 \\
\hline & & Tree $^{*} Q . d$ & $-9.75 e^{-1}$ & $6.39 e^{-1}$ & 1.521 & 0.128 \\
\hline & & Shrub* $Q .1$ & $1.25 \mathrm{e}^{-2}$ & $8.43 e^{-1}$ & 0.015 & 0.988 \\
\hline & & Tree ${ }^{*} \mathrm{Q} .1$ & $-3.64 \mathrm{e}^{-1}$ & $6.67 \mathrm{e}^{-1}$ & 0.544 & 0.586 \\
\hline
\end{tabular}

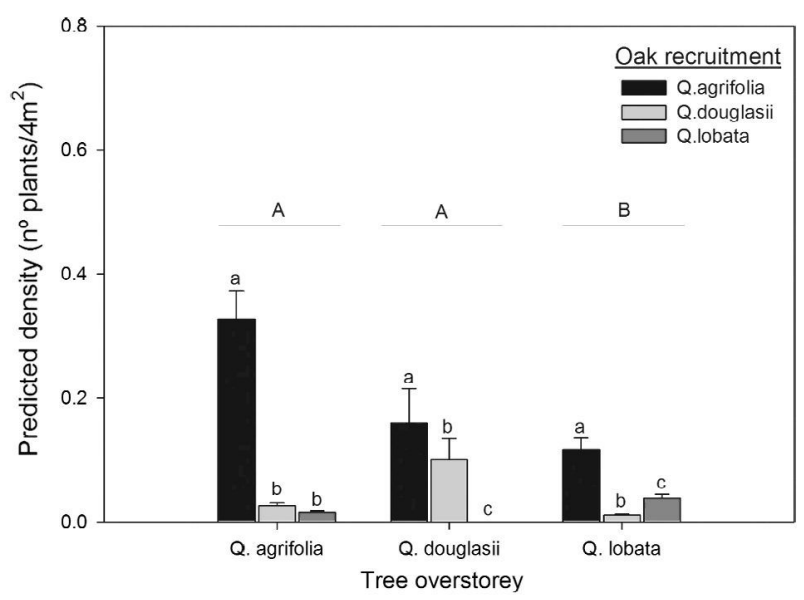

Fig. 1. Predicted density of oak recruitment (bars) depending on the tree overstorey. Error lines are $95 \%$ confidence intervals. Same low case letters above bars indicate no significant differences in young oak recruitment under each tree overstorey, and same capital letters above group of bars indicate no significant differences between different overstorey tree species.

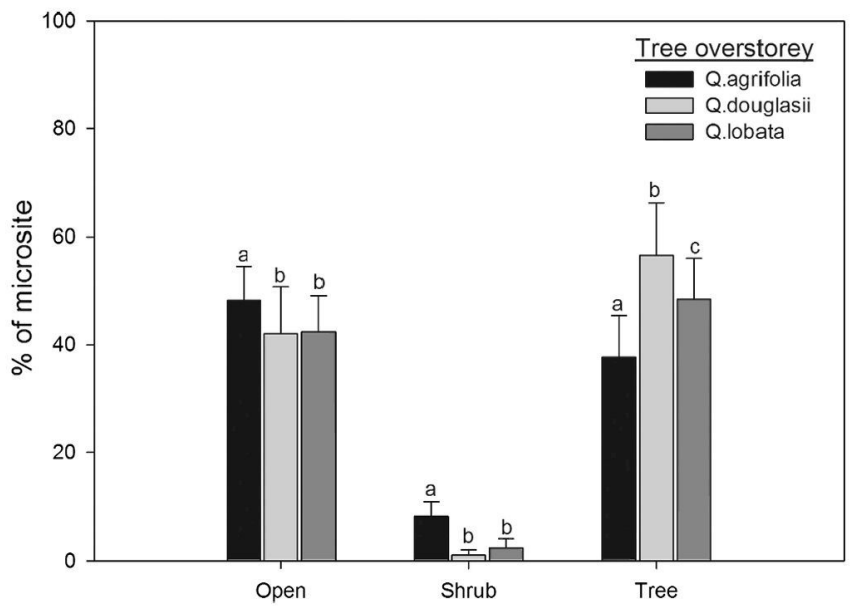

Fig. 2. Proportion of each microsite (open, shrub cover and tree cover) for areas dominated by each overstorey tree species. Error lines are $95 \%$ confidence intervals. Same letters above bars indicate no significant differences.

shrub cover as compared to $Q$. lobata and $Q$. douglasii areas $(z=7.924 ; P<0.001$; Fig. 2). However, $Q$. lobata and $Q$. douglasii areas had significantly greater tree cover $(48 \%$ and $56 \%$, respec- tively) than areas dominated by Q. agrifolia (38\%; $z=7.897$; $P<0.001$; Fig. 2). The proportion of open microsites was slightly greater in $Q$. agrifolia areas (48\%) than in Q. lobata and Q. douglasii areas ( $42 \%$ for both; Fig. 2 ).

Overall, microsite type significantly affected the density of young oaks (Table 1; Fig. 3). Two microsites (under tree and under shrub cover) showed significantly greater density of young oaks ( 0.12 and 0.17 plants per $4 \mathrm{~m}^{2}$, respectively) than in open areas (0.07 plants per $4 \mathrm{~m}^{2}$; Table 1 ; Fig. 3 ). The same microsite pattern was found across all oak species, with no significant interactions between microsite type and oak species (Table 1; Fig. 3). Overall, Poisson oak (Toxicodendron diversilobum) was the most common shrub species ( $51.1 \%$ of all shrub cover), followed by Coyote bush (Baccharis pilularis), with $35.8 \%$ of shrub cover. The rest of shrub species (Heteromeles arbutifolia, Symphoricarpos mollis, Rhamus californica, Umbellularia californica, Rosa spp.) covered less than 7\% each. Finally, the density of young oak plants was not significantly different between both study sites (Table 1 ).

\subsection{Probability and intensity of herbivory}

The probability of herbivory occurrence (Table 2) and the intensity of herbivory (Table 3) strongly depended on oak species, microsite type and site. The probability of herbivory occurrence

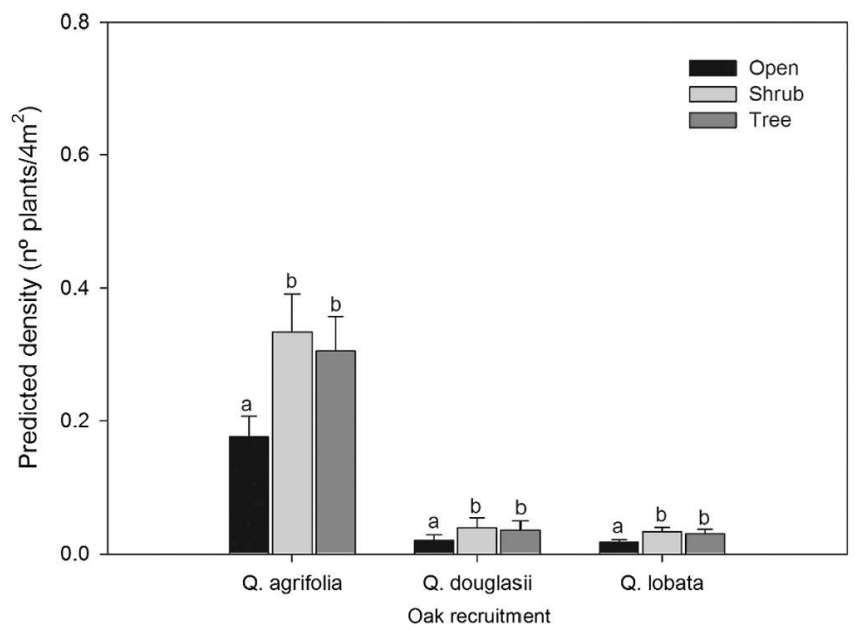

Fig. 3. Predicted density of young oaks across the three main microsites for each regenerating oak species. Error lines are $95 \%$ confidence intervals. Same letters above bars indicate no significant differences in young oak recruitment. 
Table 2

Summary of the Generalized Linear Models fitted to analyze the occurrence of herbivory.

\begin{tabular}{|c|c|c|c|c|c|c|}
\hline Predictors & Relative importance & Factors & Coeff. & $S E$ & $z$-value & $P$ \\
\hline Intercept & & & 0.687 & 0.300 & 0.301 & 0.023 \\
\hline \multirow[t]{2}{*}{ Oak species $(0)$} & 0.98 & Q. douglasii (Q.d) & 1.634 & 0.863 & 1.885 & 0.050 \\
\hline & & Q. lobata (Q.D) & -0.287 & 1.031 & 0.277 & 0.782 \\
\hline \multirow[t]{2}{*}{ Microsite (M) } & 1.00 & Shrub & -2.374 & 0.471 & 5.020 & $<0.001$ \\
\hline & & Tree & -0.918 & 0.334 & 2.738 & 0.006 \\
\hline Site $(S)$ & 0.99 & Jasper Ridge & 1.103 & 0.334 & 3.286 & 0.001 \\
\hline \multirow[t]{4}{*}{$M^{*} \mathrm{O}$} & 0.36 & Shrub * Q.d & 15.892 & 1029.122 & 0.015 & 0.988 \\
\hline & & Tree * Q.d & -0.249 & 1.375 & 0.180 & 0.857 \\
\hline & & Shrub * $Q . l$ & -15.195 & 809.707 & 0.019 & 0.985 \\
\hline & & Tree * 0.1 & -1.981 & 1.346 & 1.466 & 0.143 \\
\hline
\end{tabular}

Table 3

Summary of the multinomial $\log$-linear models (Likelihood-ratio $\chi^{2}$ test) to analyze the intensity of herbivory.

\begin{tabular}{lllll}
\hline Predictors & Importance & d.f. & LR $\chi 2$ & $P$ \\
\hline Oak species (O) & 1.00 & 10 & 49.472 & $<0.001$ \\
Microsite (M) & 1.00 & 10 & 58.288 & $<0.001$ \\
Site (S) & 1.00 & 5 & 57.983 & $<0.001$ \\
$M^{*} \mathrm{O}$ & $<0.01$ & 20 & 13.304 & 0.864 \\
\hline
\end{tabular}

on young $Q$. douglasii oaks was very high (mean probability $=0.84$ ), and significantly greater than on the other two species ( 0.53 and 0.50 for $Q$. agrifolia and Q. lobata, respectively; Table 2; Fig. 4a). Intensity of herbivory was very high on young $Q$. douglasii and $Q$. lobata plants, with $36 \%$ and $57 \%$ of the browsed plants showing the maximum browsing damage ( $>90 \%$ of the twigs damaged; Fig. 4a). In contrast, intensity of herbivory was much lower in $Q$. agrifolia plants, with only $5 \%$ of browsed plants showing maximum browsing damage. Almost $40 \%$ of the $Q$ agrifolia plants had light browsing damage ( $<10 \%$ of twigs damaged; Fig. $4 a$ ).

Microsite type also had a significant effect on herbivory probability of young oaks (Table 2), with a significant gradient probability of herbivory in the following sequence: open microsites (probability of 0.77$)>$ tree canopy $(0.50)>$ under shrub cover (0.30) (Table 2; Fig. 4b). Microsite type also affected intensity of herbivory (Table 3 ). Overall, intensity of herbivory was greater in open microsites (Fig. 4b). Predicted probability of maximum browsing damage was more than one order of magnitude higher in open areas (probability of 0.17 ) than under tree canopy (probability of 0.016; Fig. 4b). Probability of maximum browsing damage was null for young oaks growing under shrub cover (Fig, 4b). Most of the browsed young plants located under shrubs showed light browsing damage ( $<10 \%$ of twigs damaged) and most of the young plants growing under tree canopy showed low to intense levels of browsing damage (10-60\% of twigs damaged; Fig. 4b). The same microsite effects were found across all oak species for both herbivory occurrence and intensity, with no significant interactions between microsite and oak species (Tables 2 and 3). Finally, JRBP showed significantly greater probability of herbivory occurrence than SDA (Table 2) across all herbivory levels (Table 3; $P<0.05$ ). Accordingly, the number of deer pellet groups per transect was 5.4-times greater in JRBP than in SDA (Mean $\pm \mathrm{SE}=11.06 \pm 1.94$ and $2.06 \pm 0.50$ pellet groups per transect, respectively; L-R $\left.\chi_{1}^{2}=103.99 ; P<0.001\right)$.

\section{Discussion}

Our results show an overall underrepresentation of young oaks for both deciduous species (Q. lobata and $Q$. douglasii) across all sites. In contrast, regeneration of evergreen oaks ( $Q$. agrifolia) was significantly greater, even in those areas where reproductive deciduous tree species were predominant. This differential oak recruitment was particularly accentuated in $Q$. lobata areas, with (a)

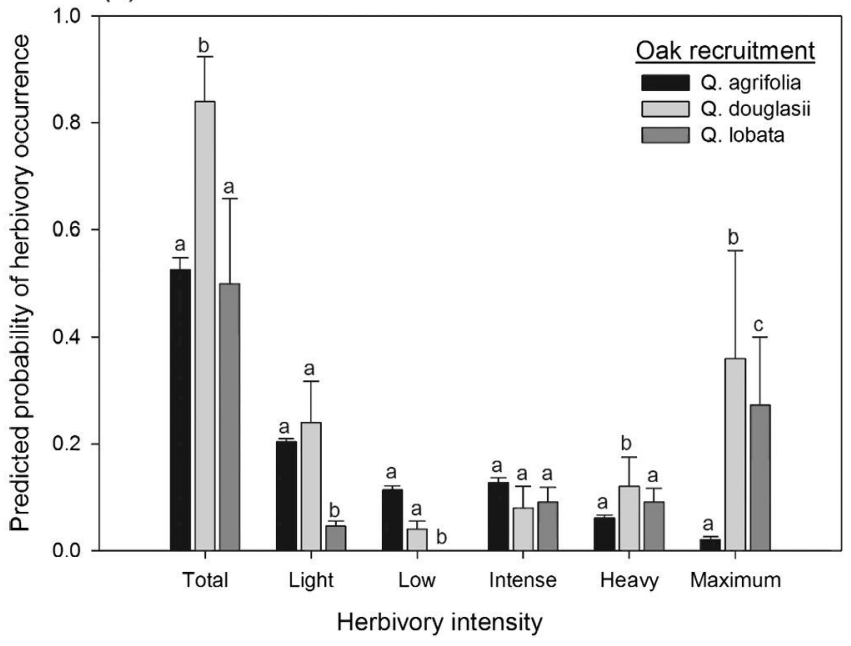

(b)

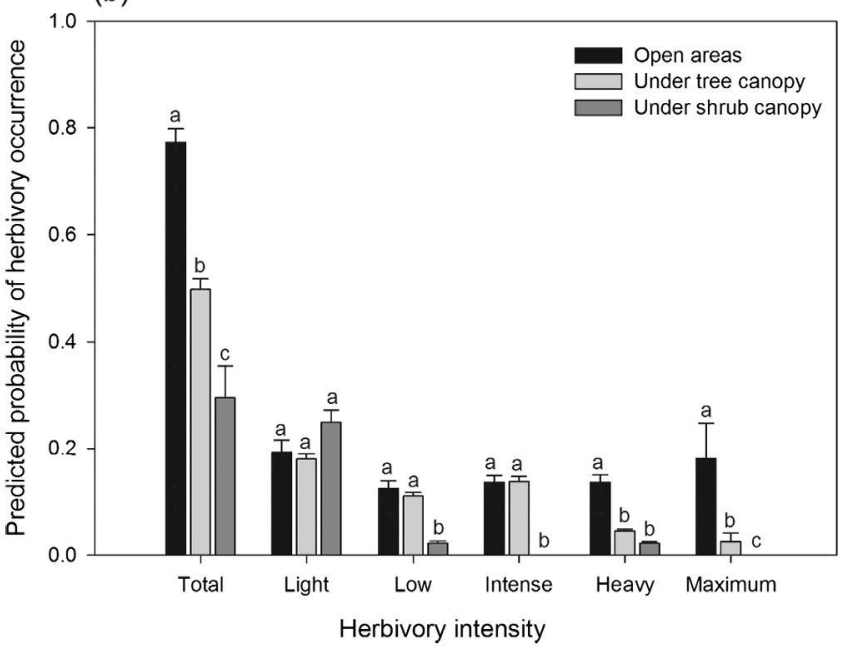

Fig. 4. Predicted probability of herbivory occurrence across different damage categories depending on (a) oak species, and (b) microsite type ( $\mathrm{N}=287$ plants). Error lines are $95 \%$ confidence intervals. Same letters above bars indicate no significant differences between species within the same damage category.

densities of young Q. agrifolia exceeding those of Q. lobata. Previous studies have also found that, in many areas, Q. lobata regenerates poorly (Griffin, 1976; Callaway, 1992; Tyler et al., 2006; Pearse et al., 2014). A recent study also highlighted that $Q$. lobata seedlings were underrepresented, with similar proportions $(\sim 33 \%)$ of each oak species ( $Q$. lobata, $Q$. douglasii and $Q$. agrifolia) growing in the understory of $Q$ lobata mature trees (Pearse et al., 2014). Our results, which go beyond seedlings (include juveniles), show greater differences, with more than $70 \%$ of the regeneration in $Q$. 
lobata-overstorey areas belonging to live oaks. Interestingly, areas dominated by Q. lobata in the overstorey showed significantly lower recruitment, regardless the regenerating oak species, with $54 \%$ lower recruitment levels than $Q$. agrifolia-overstorey areas. This could be due to the lower availability of safe microsites (shrubs) for recruitment in $Q$. lobata areas as compared to $Q$. agrifolia areas, although other factors may also have an effect, such as stronger competition with grasses, or greater herbivory pressure in Q. lobata areas where soil fertility and productivity are higher (Allen-Diaz et al., 2007). Nevertheless, further studies should examine why recruitment of $Q$. lobata was, proportionally, the least abundant under conspecifics, with approximately $1 / 3$ and $1 / 10$ lower density of own recruitment than $Q$. douglasii and $Q$. agrifolia, respectively. As a result, Quercus lobata seems to be the most vulnerable oak species in terms of species viability and persistence within these multi-specific oak savannas. Important diseases such as sudden oak death (Phytophthora ramorum) have not been found in the study area but interspecific differences in its susceptibility may have a strong effect on oak species composition at a regional scale. In this regard, areas dominated by $Q$. agrifolia in Northern California have suffered larger losses, which suggests a possible greater susceptibility of $Q$, agrifolia to sudden oak death as compared to Q. lobata and $Q$. douglasii (McPherson et al., 2010) but its effect in multi-specific oak savannas is still largely unknown.

Our findings also reveal insufficient regeneration for $Q$. douglasii when compared to $Q$ agrifolia. However, recruitment rates of $Q$. douglasii were greater than those of $Q$. lobata, particularly under conspecifics. Pearse et al. (2014) also identified recruitment limitation in $Q$. douglasii as compared to $Q$ agrifolia seedlings, but did not find greater recruitment of $Q$. agrifolia under $Q$. douglasii mature trees. This might be because, unlike $Q$. lobata savannas, a significant area of California woodlands is dominated by extensive, monospecific $Q$. douglasii stands (Allen-Diaz et al., 2007) and, thus, colonization by other Quercus species could be more unlikely. Here, in areas where the three species co-occur, Q. agrifolia showed proportionally greater recruitment, even in areas where Q. lobata and Q. douglasii where predominant in the overstorey, providing strong evidence of a biased regeneration that may drive the replacement (or displacement) of deciduous oaks by live oaks in areas where both overlap. Griffin (1976) already noticed that live oak regeneration was consistently more obvious than that of deciduous oaks, arguing that $Q$ agrifolia was slowly moving into shady spots in the savannas, with the advantage of being more browse-resistant than deciduous oaks (Lindsdale and Tomich, 1953; Griffin, 1971). Such anecdotal observations are now confirmed with our data, at least in areas where browsing pressure is low (SDA site) to moderate (JRBP site). In addition, we also found that $Q$. agrifolia was less vulnerable to browsing (lower herbivory occurrence and intensity), than the other two deciduous oaks, which is probably favoring $Q$. agrifolia regeneration. In addition, areas dominated by Q. agrifolia showed significantly greater shrub cover than areas dominated by either deciduous oaks. This suggests greater availability of safe microsites for regeneration in areas dominated by evergreen oaks. Further studies should fully analyze whether the same differential regeneration patterns occur in co-dominated savannas with no browsers. Nevertheless, previous studies also demonstrated that recruitment failure in $Q$. lobata is actually occurring even in areas with no large herbivores (Pearse et al., 2014). Acorn predation has been also argued as an important factor limiting $Q$. lobata regeneration (Griffin, 1971; Tyler et al., 2002) but no differences have been found between $Q$. lobata and Q. agrifolia in overall acorn predation, with maximum emergence rates of $30 \%$ and $32 \%$, respectively, in a 4-year study (Tyler et al., 2002).

Interestingly, we found that the effect of microsite on tree recruitment was similar for the three study species. Young oaks were significantly associated with shrub cover, suggesting a facili- tation effect. Shrubs clearly operated as nurse microsites, reducing both occurrence and intensity of herbivory. This facilitation pattern across species suggests similar regeneration niches for evergreen and deciduous oaks, at least in areas where large herbivores are present. Callaway (1992) found shrub facilitation on $Q$. douglasii seedlings but not on $Q$. lobata seedlings. However, most Mediterranean oak species, both evergreen and deciduous, have been proved to benefit from shrubs, particularly in dry environments (Gómez-Aparicio et al., 2004; Smit et al., 2008), or when browsing pressure is high (Perea and Gil, 2014b; Perea et al., 2016).

In areas where water is not a limiting factor and browsing pressure is negligible, oak recruitment may not benefit from shrub protection (Perea and Gil, 2014a). It is well known that Q. lobata seedlings produce a very long root to reach permanent water (Mahall et al., 2009) and, thus, may not benefit from abiotic facilitation (reduced water stress). However, other studies found greater survival and establishment of $Q$. lobata under protection against ungulates (Davis et al., 2011), which would confirm our results indicating that all oak species benefit from biotic facilitation via protection against browsers. It seems plausible that shrub facilitation could operate along a continuum, with some oak species benefitting more than others. In fact, our results show that under browsing pressure all oak species benefit from shrub protection, reducing herbivory occurrence and, particularly, browsing intensity. However, light levels of herbivory ( $<10 \%$ of twigs) showed no differences across microsites, suggesting that an increase of browsing pressure may enhance the facilitative effects of shrubs through biotic mechanisms of plant facilitation (Perea and Gil, 2014a), making shrub cover a more valuable regeneration niche.

Tree cover was also an important microsite for regeneration but showed lower recruitment rates and greater herbivory damage (both occurrence and intensity) than under shrub cover. These results confirm that shrubs provide a complementary facilitation against browsers since abiotic facilitation (mainly reduction in water stress by shading; Smit et al., 2008) is common under trees and shrubs, or possibly greater under the dense shade of trees (Perea et al., 2016).

In contrast, open microsites represent unsuitable areas for recruitment for the three study oaks given the low density of young oaks and the high herbivory damage (both occurrence and intensity). However, live oaks ( $Q$, agrifolia) have shown slightly greater capability to colonize open areas (i.e., greater recruitment rates), probably due to their greater ability to escape intense browsing damage. Previous studies also highlighted the ability of live oaks to colonize new areas, particularly under shrub cover (Callaway and Davis, 1998; Zavaleta and Kettley, 2006) but also in open gaps (Griffin, 1976). Therefore, browsing pressure seems to be an important factor homogenizing and reducing the abundance of favorable regeneration niches for the most herbivoresensitive species (i.e., deciduous oaks).

Species coexistence and interspecific variation in regeneration niche might be enhanced in areas with low or null browsing pressure where deciduous oaks might outcompete live oaks (e.g., in wetter - Q. lobata- or drier - Q. douglasii - soils), without suffering the detrimental effects of herbivory. These ideas align with those of Davis et al. (2011), who showed that herbivores exert a stronger influence than fecundity or environmental variables on the demography of $Q$. lobata. Further studies should examine whether the currently biased tree regeneration we have documented is mostly favored by differential browsing intensity on evergreen as compared to deciduous oaks and whether species turnover becomes more accentuated in the near future, in both adult and juvenile stages. Finally, we posit that, for the management and conservation of multi-specific oak savannas, regeneration of deciduous oaks should be prioritized over that of live oaks in order to maintain greater levels of biodiversity and reduce biotic homogenization. 


\section{Acknowledgements}

We would like to thank Jonathan Griffon, Irene Moreno and Xurxo Gago for their help with fieldwork. We are also grateful to all the staff from Jasper Ridge Biological Preserve and the Stanford Dish Area (Land Use and Environmental Planning Office) for logistical support. RP was supported by a Marie Curie International Outgoing Fellowship (FP7-PEOPLE-2013-IOF-627450).

\section{References}

Allen-Diaz, B.H., Standiford, R.B., Jackson, R.D., 2007. Oak woodlands and forests. In: Barbour, M.G. Keeler-Wolf, T. Schoenherr, A.A (Eds.), Terrestrial Vegetation of California. University of California Press, Berkeley, USA, pp. 313-338.

Bakker, J.P., Olff, H., Willems, J.H., Zobel, M., 1996. Why do we need permanent plots in the study of long-term vegetation dynamics? J. Veg. Sci. 7 (2), 147-155.

Bartolome, J.W., Muick, P.C., McClaran, M.P., 1987. Natural regeneration of Californian hardwoods. In: Plumb, T.R., Pillsbury, N.H. (Eds.), Proceedings of the Symposium on Multiple-Use Management of California's Hardwood Resources. Forest Service general technical report PSW-100. Pacific Southwest Forest and Range Experiment Station, Forest Service, USDA, Albany (CA), pp. 2631.

Barton, K., 2015. MuMIn: Multi-Model Inference. R package version 1.15.1 <https:// CRAN.R-project.org/package=MuMIn>

Bergmeier, E., Petermann, J., Schröder, E., 2010. Geobotanical survey of woodpasture habitats in Europe: diversity, threats and conservation. Biodivers Conserv. 19, 2995-3014.

Bocek, B., Reese, E., 1992. Land Use History of Jasper Ridge Biological Preserve. Jasper Ridge Biological Preserve, Stanford University.

Burnham, K.P., Anderson, D.R., 2002. Model Selection and Multimodel Inference: A Practical Information-Theoretic Approach. Springer Verlag, New York.

Callaway, R.M., 1992. Effect of shrubs on recruitment of Quercus douglasii and Quercus lobata in California. Ecology 73, 2118-2128.

Callaway, R.M., D'Antonio, C.M., 1991. Shrub facilitation of coast live oak establishment in central California. Madroño 38, 158-169.

Callaway, R.M., Davis, F.W., 1998. Recruitment of Quercus agrifolia in central California: the importance of shrub-dominated patches. J. Veg. Sci. 9, 647-656.

Campos, P., Huntsinger, L., Oviedo, J.L., Starrs, P.F., Diaz, M., Standiford, R.B., Montero, G. (Eds.), 2013. Mediterranean Oak Woodland Working Landscapes: Dehesas of Spain and Ranchlands of California. Landscape Series, Springer.

Crawley, M.J., 2012. The R Book. John Wiley \& Sons, London.

Crowther, T.W., Glick, H.B., Covey, K.R., Bettigole, C., Maynard, D.S., Thomas, S.M. Smith, J.R., Hintler, G., Duguid, M.C., Bradford, M.A., 2015. Mapping tree density at a global scale. Nature 525, 201-205.

Davis, F.W., Tyler, C.M., Mahall, B.E., 2011. Consumer control of oak demography in a Mediterranean-climate savanna. Ecosphere 2, 108. http://dx.doi.org/10.1890/ ES11-00187.1.

Davis, F.W. Baldocchi, D.D., Tyler, C.M., 2016. Oak Woodlands. In: Mooney, H.A., Zavaleta, E. (Eds.), Ecosystems of California. University of California Press, Berkeley, pp. 509-534.

Dobson, A.J., 2002. An Introduction to Generalized Linear Models. Chapman \& Hall, New York, USA.

Fischer, J., Stott, J., Zerger, A., Warren, G., Sherren, K., Forrester, R.I., 2009. Reversing a tree regeneration crisis in an endangered ecoregion. Proc. Natl. Acad. Sci. USA $106,10386-10391$.

Fox, J., Weisberg, S., 2011. An R Companion to Applied Regression. Sage, Thousand Oaks.

Gómez-Aparicio, L., Zamora, R., Gómez, J., Castro, J., Baraza, E., 2004. Applying plant facilitation to forest restoration: a meta-analysis for the use of shrubs as a nurse plant. Ecol. Appl. 14, 1128-1138.

Gómez-Aparicio, L., Pérez-Ramos, I.M., Mendoza, L., Matías, L., Quero, J.L., Castro, J. Zamora, R., Marañón, T., 2008a. Oak seedling survival and growth along resource gradients in Mediterranean forests: implications for regeneration in current and future environmental scenarios. Oikos 117, 1683-1689.

Gómez-Aparicio, L., Zamora, R., Castro, J., Hódar, J.A., 2008b. Facilitation of tree saplings by nurse plants: micro-habitat amelioration or protection against herbivores? J. Veg. Sci. 19, 161-172.

Gordon, D.R., Rice, K.J., 2000. Competitive suppression of Quercus douglasii (Fagaceae) seedling emergence and growth. Am. J. Bot. 87, 986-994.

Griffin, J.R., 1971. Oak regeneration in the upper Carmel Valley, California. Ecology $52,862-868$.

Griffin, J.R., 1976. Regeneration in Quercus lobata savannas, Santa Lucia Mountains, California. Am. Midl. Nat. 95, 422-435.

Grubb, P.J., 1977. The maintenance of species richness in plant communities: the importance of the regeneration niche. Biol. Rev. 52, 107-145.

Hulme, P.E., 1996. Herbivory, plant regeneration, and species coexistence. J. Ecol. 84 (4), 609-615

Ibañez, I., Clark, J.S., Dietze, M.C., 2008. Estimating colonization potential of migrant tree species. Glob. Change Biol. 15, 1173-1188.

Kueppers, L.M., Snyder, M.A., Sloan, L.C., Zavaleta, K.S., Fulfrost, B., 2005. Modeled regional climate change and California endemic oak ranges. Proc. Natl. Acad. Sci. $102,16281-16286$
Lindsdale, J.M., Tomich, P.Q., 1953. A Herd of Mule Deer. Univ. Calif. Press, Berkeley and Los Angeles, CA, USA.

López-Sánchez, A., Schroeder, J., Roig, S., Sobral, M., Dirzo, R., 2014. Effects of cattle management on oak regeneration in Northern Californian Mediterranean Oak Woodlands. PLoS ONE 9, e105472.

López-Sánchez, A., Perea, R., Dirzo, R., Roig, S., 2016. Livestock vs. wild ungulate management in the conservation of Mediterranean dehesas: implications for oak regeneration. For. Ecol. Manage. 362, 99-106.

Mahall, B.E., Tyler, C.M., Cole, E.S., Mata, C., 2009. A comparative study of oak (Quercus, Fagaceae) seedling physiology during summer drought in southern California. Am. J. Bot. 96, 751-761.

Manning, A., Fischer, I., Lindnmayer, D., 2006. Scattered trees are keystone structures-implications for conservation. Biol. Cons. 132, 311-321.

McClaran, M.P., Bartolome, J.W., 1989. Fire related recruitment in stagnant Quercus douglasii populations. Can. J. For. Res. 19, 580-585.

McMahon, D.E., Pearse, I.S., Koenig, W.D., Walters, E.L., 2015. Tree community shifts and Acorn Woodpecker population increases over three decades in a Californian oak woodland. Can. J. For. Res. 45 (8), 1113-1120.

Mclauglin, B.C. Zavaleta, E.S., 2012. Predicting species responses to climate change: demography and climate microrefugia in California valley oak (Quercus lobata). Glob. Change Biol. 18, 2301-2312.

McPherson, Brice A., Mori, Sylvia R., Wood, David L., Storer, Andrew J., Svihra, Pavel, Kelly, Maggi N., Standiford, Richard B., 2010. Responses of oaks and tanoaks to the sudden oak death pathogen after 8 years of monitoring in two coastal California forests. For. Ecol. Manage. 259, 2248-2255.

Muick, P.C., Bartolome, J.W., 1987. Assessment of natural regeneration of oaks in California. A report to the California Department of Forestry and Fire Protection, Sacramento (CA).

Nixon, K.C., 1993. Infrageneric classification of Quercus (Fagaceae) and typification of sectional names. Ann. Sci. Forest. 50 (Suppl. 1), 25-34.

Palmer, B., 2003. Committee for Dish recreation use issues final report. Stanford News Service, Stanford, CA.

Pearse, I.S., Griswold, S., Pizarro, D., Koenig, W.D., 2014. Stage and size structure of three species of oaks in central coastal California. Madroño 61, 1-8.

Perea, R., Gil, L., 2014a. Shrubs facilitating seedling performance in ungulatedominated systems: biotic versus abiotic mechanisms of plant facilitation. Eur. J. Forest Res. $133,525-534$.

Perea, R., Gil, L., 2014b. Tree regeneration under high levels of wild ungulates: the use of chemically vs. physically-defended shrubs. For. Ecol. Manage. 312 47-54.

Perea, R., Girardello, M., San Miguel, A., 2014. Big game or big loss? High deer populations are threatening woody plant diversity and vegetation dynamics. Biodivers. Conserv. 23, 1303-1318.

Perea, R., Perea-Garcia-Calvo, R., Díaz-Ambrona, C., San Miguel, A., 2015. The reintroduction of a flagship ungulate Capra pyrenaica: assessing sustainability by surveying woody vegetation. Biol. Cons. 181, 9-17.

Perea, R. López-Sănchez, A. Roig S, 2016. The use of shrub cover to preserve Mediterranean oak dehesas: a comparison between sheep, cattle and wild ungulate management. Appl. Veg. Sci. 19, 244-256.

Pérez-Ramos, I.M., Urbieta, I.R., Zavala, M.A., Marañón, T., 2012. Ontogenetic conflicts and rank reversals in two Mediterranean oak species: implications for coexistence. J. Ecol. 100, 467-477.

Plieninger, T., Pulido, F.J., Konold, W., 2003. Effects of land-use history on size structure of holm oak stands in spanish dehesas: implications for conservation and restoration. Environ. Conserv. 30, 61-70.

Plieninger, T., 2006. Habitat loss, fragmentation and alteration-quantifying the impact of land-use changes on a Spanish dehesa landscape by use of aerial photography and GIS. Landscape Ecol. 21, 91-105.

Pulido, F.J., Díaz, M., 2005. Regeneration of a mediterranean oak: a whole-cycle approach. Ecoscience 12, 92-102.

Pulido, F.J., Díaz, M., de Trucios, S.J.H., 2001. Size structure and regeneration of spanish holm oak Quercus ilex forests and dehesas: effects of agroforestry use on their long-term sustainability. For. Ecol. Manage. 146, 1-13.

Pulido, F., García, E., Obrador, J.J., Moreno, G., 2010. Multiple pathways for tree regeneration in anthropogenic savannas: incorporating biotic and abiotic drivers into management schemes. J. Appl. Ecol. 47, 1272-1281.

$\mathrm{R}$ Core Team, 2016. R: A Language and Environment for Statistical Computing. $\mathrm{R}$ Foundation for Statistical Computing, Vienna, Austria <https://www.r-project. org $>$.

Smit, C., den Ouden, J., Díaz, M., 2008. Facilitation of holm oak recruitment by shrubs in Mediterranean open woodlands. J. Veg. Sci. 19, 193-200.

Tyler, C.M., Mahall, B.E., Davis, F.W., Hall, M., 2002. Factors limiting recruitment in valley and coast live oak. In: Standiford, R.B., et al. (Eds.), Proceedings of the Fifth Symposium on Oak Woodlands: Oaks in California's Changing Landscape. Pacific Southwest Research Station, Forest Service, U.S. Department of Agriculture, pp. 565-572.

Tyler, C., Kuhn, B., Davis, F., 2006. Demography and recruitment limitations of three oak species in California. Quart. Rev. Biol. 81, 127-152.

Tyler, C., Davis, F.W., Mahall, B.F., 2008. The relative importance of factors affecting age-specific seedling survival of two co-occurring oak species in southern California. For. Ecol. Manage. 225, 3063-3074.

Valladares, F., Bastias, C.C., Godoy, O., Granda, E., Escudero, A., 2015. Species coexistence in a changing world. Front. Plant Sci. 6, 866. http://dx.doi.org/ $10.3389 / \mathrm{fpls} .2015 .00866$.

Venables, W.N., Ripley, B.D., 2002. Modern Applied Statistics With S. Springer, New York. 
Zavaleta, E.S., Kettley, L.S., 2006. Ecosystem change along a woody invasion chronosequence in a California grassland. J. Arid Environ. 66, 290-306.

Zavaleta, E.S., Hulvey, K.B., Fulfrost, B., 2007. Regional patterns of recruitment success and failure in two endemic California oaks. Divers. Distrib. 13, 735-745.
Zuur, A.F., Ieno, E.N., Walker, N.J., Saveliev, A.A., Smith, G.M., 2009. Mixed effects modelling for nested data. In: Zuur, A.F., leno, E.N., Walker, N.J., Saveliev, A.A Smith, G.M. (Eds.), Mixed Effects Models and Extensions in Ecology with R. Springer, New York, pp. 101-142. 